\title{
THE AUTHORITY OF THE SUB-DISTRICT HEAD IN EVALUATING DRAFT REGULATION OF THE VILLAGE REGARDING VILLAGE BUDGET IN CENTRAL BENGKULU BASED ON THE REGENT'S REGULATION OF CENTRAL BENGKULU NUMBER 34 OF 2018 REGARDING THE AUTHORITY DELEGATION OF THE REGENT TO THE SUB-DISTRICT HEAD IN EVALUATING DRAFT REGULATION OF THE VILLAGE REGARDING VILLAGE BUDGET AND DRAFT REGULATION OF THE VILLAGE ABOUT VILLAGE BUDGET AMENDMENT
}

By:

Neny Zarniawati, Elektison Somi, Amancik

\begin{abstract}
The researcher will discuss the Sub-Districts Head authority in evaluating Draft Regulation of the Village regarding Village Budget (APBDes) in Central Bengkulu Regency based on the Regent's Regulation of Central Bengkulu Number 34 of 2018 regarding the Authority Delegation of the Regent to the Sub-District Head in evaluating Draft Regulation of the Village regarding Village Budget and Draft Regulation of the Village about Village Budget Amendment ( $p$-APBDes). The purpose of this research was to find out and to analyze the authority of the Sub-District Head in terms of evaluating the Draft Regulation of the Village regarding APBDes in Central Bengkulu Regency based on the Regent's Regulation of Central Bengkulu Number 34 of 2018 regarding the Authority Delegation of the Regent to the SubDistrict Head in evaluating Draft Regulation of the Village Regarding APBDes and Draft Regulation of the Village about $p$-APBDes. This research was normative legal research. Data sources used were primary and secondary data sources. In collecting the data, the researcher used the methods of library studies and field studies. After the research was conducted, it can be concluded that the authority of the Sub-District Head in evaluating the Draft Regulation of the Village regarding APBDes and P-APBDes in Central Bengkulu Regency was carried out based on the regulation mandate that stipulated in Law No. 6 of 2014 about Village, Law No. 23 of 2014 about Local Government, Government Regulations No. 43 of 2014 about Regulations for Implementing Village Laws, Government Regulations No. 17 of 2018 about sub-districts, Regulation of Minister of Home Affairs No. 20 of 2018 about Village Financial Management and Regent's Regulation of Central Bengkulu number 34 of 2018 regarding the Authority Delegation of the Regent to the Sub-District Head in evaluating Draft Regulation of the Village Regarding APBDes and Draft Regulation of the Village about $p$-APBDes.
\end{abstract}

Keywords: Sub-district's Authority, Village Regulation, APBDesa. 


\section{A. INTRODUCTION}

\section{Research Background}

The implementation of Local Governments of Provincial and Regency/City consists of the Head of Local Government and Regional House of Representatives were assisted by the Local Devices. Based on the provisions of Article 209 Paragraph (2) of Law Number 23 of 2014 concerning Local Government, it determines that the Regency/City Local Devices consists of the Local Secretariat, DPRD Secretariat, Inspectorate, Office, Agency, and subDistrict. ${ }^{1}$

In line with the enactment of Law Number 23 of 2014 about Local Government, the status of the sub-district now is a Local Device of Regencies/Cities that equal with the offices and agencies. Sub-districts were formed to improve the coordination of government administration, which means that with the existence of Sub-districts, the head of Sub-district as the highest leader in the Sub-district had considerable authority in the area. In detail, the authority of the head of Sub-district is explained in Article 226 Paragraph (1) of Law Number 23 of 2014 about Local

\footnotetext{
${ }^{1}$ Article 209 Paragraph (2) Law Number 23 of 2014 concerning Local Government.
}

Government, which states that in addition to carrying out the duties as referred to in Article 225 paragraph (1), the sub-district head has delegated part of the authority of the Regent/Mayor to carry out part of the Government Affairs which are the authority of the Regency/City Local Government. $^{2}$

Therefore, based on the provisions of Article 226 Paragraph (1), the subdistrict head has the authority delegated or given by the Regent/Mayor to handle part of the regional autonomy affairs in his area. Delegation of authority is one way to legally delegate power/authority. Delegation is not a full delegation, it means that it does not include the authority to form policies, because the authority to form such policies is in the hands of officials who are attached by attribution. ${ }^{3}$ The delegation of authority is As the Sub-District was formed to improve the coordination of government administration, the Sub-District Head must provide public services in the subdistrict and also empower the rural and village communities. The Sub-District Head has the task of carrying out the fostering and supervision of the village government, one of which is conducting the fostering and orderly administration

\footnotetext{
${ }^{2}$ Ibid, Article 226 (1)

${ }^{3}$ Safri Nugraha, et al, 2007, Hukum Administrasi Negara, Central For Law and Good Governance Studies, Faculty of Law, University of Indonesia, p. 27
} 
Neny Zarniawati, Elektison Somi, Amancik

of the village administration. In carrying out its role of providing guidance and supervision, the Sub-District Head processes the making of Village Regulations (Perdes). In the context of Village Regulation, the concept of supervision can be carried out by testing it. The testing mechanism through cancellation is as a form of supervision of its authority is left to the Regent/Mayor with benchmarks if something of Village Regulation is contrary to higher provisions and/or contrary to the public interest. $^{4}$

One type of Village Regulation that can be tested or can be evaluated is the Draft Regulation of the Village concerning Village Budget (Perdes APBDes). APBDes is a village Regulation that contains sources of revenue and allocation of Village expenditure within one year. This APBDes consists of Village income, Village expenditure, and Village financing. ${ }^{5}$ Village income sources come from Original Village Government Revenue and come from transfers, namely Local Tax Results of Regency/City and Local Retribution, Village Fund Allocation ( $A D D)$ which is part of the balance funds received by the

\footnotetext{
${ }^{4}$ Article 87, Government Regulation No. 43 of 2014 concerning Regulations for the Implementation of Law No. 6 of 2014 concerning Villages.

5 Article 9, Paragraph (1), Minister of Home Affairs
}

Bengkoelen Justice, Vol. 10 No.2 November 2020

Regency/City and the most source comes from National State (revenue and expenditure) Budget $(A P B N)$ in the form of Village Funds $(D D)$. determined based on statutory regulations.

In Central Bengkulu Regency, the implementing regulations that used as the basis for the formation of village regulations related to the provisions regarding the delegation of authority from the Regent to the Sub-District Head are regulated in Article 2 (1) of Regent's Regulation of Central Bengkulu number 34 of 2018 regarding the Authority Delegation of the Regent to the SubDistrict Head in evaluating Draft Regulation of the Village Regarding APBDes and Draft Regulation of the Village about $\mathrm{p}-A P B D e s$ which reads as follows:

"The Regent delegated authority to the sub-district head in evaluating Draft Regulation of the Village Regarding Village Budget and Draft Regulation of the Village about Village Budget Amendment".

The authority delegation is intended to ensure that the products produced are not contrary to the regulations issued by the Central Government or the Local Government and as a manifestation of guidance and supervision carried out by Sub-districts to Villages in their working area. By Minister of Home Affairs Regulation Number 20 of 2018 concerning Management of Village 
Neny Zarniawati, Elektison Somi, Amancik

Finances, all Village Revenues must be documented in the Perdes regarding APBDes. ${ }^{6}$ This means that the delegation of authority from the Regent to the SubDistrict Head is intended to accelerate decision making related to the interests and needs of the local community and to bring government services closer to the community so that it becomes faster and more quality.

In principle, within the 20 days since the Perdes was submitted to the Sub-District Head, the Sub-District Head together with the evaluation team must evaluate the entire draft of Perdes proposed. If within the period the Perdes are not returned, then the Perdes are declared valid by themselves. If within the time the Perdes are not returned, the perdes are declared valid by themselves. However, if it is declared not following higher laws, public interests, and the Village Government Work Plan (RKP Desa), the Village Government is obliged to improve by the specified deadline. As based on Article 101 Paragraph (4) Government Regulation Number 43 of 2014 concerning Regulations for Implementing Law Number 6 of 2014 about Village, the stipulation of Village Regulations about APBDes no later than $31^{\text {st }}$ of December of the current year. ${ }^{7}$ Implicitly, this

\footnotetext{
${ }^{6}$ Ibid.

${ }^{7}$ Article 101 Paragraph (4) Government
}

Bengkoelen Justice, Vol. 10 No.2 November 2020 provision requires that the APBDes be established earlier.

However, the facts that have been found in sub-districts of Central Bengkulu Regency, the stipulation of Perdes on $A P B D e s$ often experience delays from the time limits set above. While, based on the provisions of Article 99 Paragraph (2) Regulation of the Minister of Finance of the Republic of Indonesia No. 225/PMK.07/2017 regarding the Second Amendment to the Minister of Finance Regulation No. 50/PMK.07/2017 regarding Management of Transfers to the Regions and Village Funds, that the disbursement of the first step of Village funds by $20 \%$ was carried out in January, the second step of Village funds by $40 \%$ was carried out in March and the third step of Village funds by $40 \%$ done in July. $^{8}$

The delay as explained is certainly very influential for the Village Government to carry out their tasks. This encourages the writer to conduct the research on the delegation of the Regent's authority to the Sub-District Head in terms of Evaluation of Village Budget

Regulation Number 43 of 2014 Concerning the Implementation of Law Number 6 of 2014 concerning Villages.

${ }^{8}$ Regulation of the Minister of Finance of the Republic of Indonesia No. 225/PMK.07/2017 Regarding the Second Amendment to the Minister of Finance Regulation No. 50/PMK.07/2017 Regarding Management of Transfers to Local and Village Funds. 
with the Title "The Authority of The

Sub-District Head in Evaluating Draft

Regulation of The Village Regarding

Village Budget in Central Bengkulu

Based on The Regent's Regulation of

Central Bengkulu Number 34 of 2018

Regarding the Authority Delegation of

The Regent to The Sub-District Head in

Evaluating Draft Regulation of The

Village Regarding Village Budget and

Draft Regulation of The Village About

Village Budget Amendment".

\section{Identification of the Problems}

Based on the background above, the following problems can be formulated:

How is the authority of the SubDistrict Head in Evaluating Draft Regulation of the Village Regarding Village Budget in Central Bengkulu Regency Based on the Regent's Regulation of Central Bengkulu Regency Number 34 of 2018 Regarding the Authority Delegation of the Regent to the Sub-District Head in Evaluating Draft Regulation of the Village Regarding Village Budget and Draft Regulation of the Village about Village Budget Amendment?

\section{B. RESEARCH METHODS}

\section{Type of Research}

This type of research was normative legal research. Normative legal research examines the principles or rules of law as a building system associated with a legal event. This research was conducted to provide legal arguments as a basis for determining whether an event was right or wrong and how it would be according to law. ${ }^{9}$

\section{Data Sources}

\section{a. Primary data}

Primary data is data that researchers obtained directly from interviews with the Head of Community and Village Empowerment Office of Central Bengkulu Tengah Regency, the Head of Village Government Empowerment Section, the Head of the Village Financial Management Section and the Head of the Community and Village Government Sections of several Subdistricts in Central Bengkulu Regency which were the Team Evaluation of Village Budget (APBDes) in each Sub-District.

\section{b. Secondary Data}

The secondary data referred were

${ }^{9}$ Mukti fajar and yulianto achmad, 2017, Dualisme Penelitian Hukum Normatif dan Empiris, the fourth printed, Yogyakarta, Student Library, p.36 
included primary legal material and secondary legal material in the form of Basic Norms, Legislation, results of scientific research, books, and so on. ${ }^{10}$

1. Primary legal materials

Primary legal materials were the legal materials that have the binding force of law as the primary basis used in this study is:

a. Law Number 6 of 2014 about Village;

b. Law Number 23 of 2014 about Local Government;

c. Government Regulation

Number 43 of 2014 about rules for Implementing Village Laws;

d. Government Regulation Number 17 of 2018 about SubDistricts;

e. Minister of Finance Regulation Number 225 of 2017 about Second Amendment to Minister of Finance Regulation Number 50/PMK.07/2017 about Management of Transfers to Local and Village Funds;

f. Regulation of the Minister of Home Affairs Number 20 of 2018 about Management of Village Finances;

g. Regulation of the Minister of Finance Number 205/PMK.07/2019 about Management of Village

10 Amirudin, Zainal Asikin, 2004, Pengantar Metode Penelitian Hukum, Jakarta, Raja Grafindo persada, p.30
Funds; and

h. Regulation of the Regent of Central Bengkulu Regency No. 34 of 2018 about Authority Delegation of the Regent to the Sub-District Head in Evaluating Draft Regulation of the Village Regarding Village Budget and Draft Regulation of the Village about Village Budget Amendment.

2. Secondary legal material was legal materials that can help analyze and understand primary legal materials, such as research results, seminar results, work from the legal community, and other documents relating to the authority of the sub-district head in Draft Regulation of the Village regarding Village Budget.

\section{Method of Data Collection}

1. Literature Study

This method was conducted by carrying out a series of activities such as reading, studying, taking notes, and making reviews of library materials that are related to the problem to be studied.

2. Field Study

The field study was conducted to obtain primary data by using direct interview techniques with respondents who had been previously planned. Interviews are conducted directly and 
openly by holding questions and answers to get information or free answers therefore the data obtained is as expected.

\section{Data Analysis}

Analysis of the results of this research is done by criticizing, supporting, or commenting, then making a conclusion on the results of the research with their thoughts and the help of a literature review. The analytical method for normative legal research type in the form of a prescriptive method is the analysis method that provides an assessment (justification) of the object being investigated whether it is right or wrong, or what should be according to law. ${ }^{11}$

\section{RESULTS AND DISCUSSION}

The laws and regulations used in analyzing the authority of the Sub-District Head in Evaluating Draft Regulation of the Village regarding Village Budget in Central Bengkulu Regency Based on the Regent's Regulation of Central Bengkulu Regency Number 34 of 2018 regarding the Authority Delegation of the Regent to the Sub-District Head in Evaluating Draft Regulation of the Village regarding

\footnotetext{
${ }^{11}$ M.Endriyo Susila et al, 2007 Buku Pedoman Penulisan Hukum, Yogyakarta: Faculty of Law, University of Muhammadiyah Yogyakart. p.40-41
}

Village Budget and Draft Regulation of the Village regarding Village Budget Amendment include:

\section{Law Number 6 of 2014 about Village}

Law Number 6 of 2014 about Village in Article 112 paragraph (2) states that the Government, Provincial Government, and the Government District/City may delegate supervision to the local device. ${ }^{12}$ The authority delegation carried out by the Regent of Central Bengkulu Regency to the subdistrict Head, which is under the umbrella of Article 112 paragraph (2) of Law Number 6 of 2014 about Village, aims to be able to provide guidelines for participatory development planning for the Village as the spearhead of development implementation. With the guidelines for the preparation of Development Planning, it is hoped that the Village set up the APBDes which is a source of funding in the Village appropriately, in accordance with applicable regulations, and can improve the welfare of the Village community, so as to encourage accelerated rural development.

\section{Law Number 23 of 2014 about Local}

\footnotetext{
${ }^{12}$ Article 112 paragraph (2) of Law Number 6 of 2014 about Village.
} 
Neny Zarniawati, Elektison Somi, Amancik

\section{Government}

As explained in Article 209 paragraph (2) of Law Number 23 of 2014 about Local Government, the Sub-district is one of the Regencies/Cities local devices. The SubDistrict Head as the leader of the Subdistrict Head as regulated in Article 224 paragraph (1) of Law Number 23 of 2014 about Local Government, must be able to coordinate all government affairs in the Sub-district, then the Sub-District Head must also provide public services in the Sub- district. Sub-district head has the task and the responsibility to the Regent/Mayor through Regional Secretary as explained in Article 225 of Law Number 23 of 2014 about Local Government and the Sub-District Head also gets delegated authority, this is regulated in Article 226 of Law Number 23 of 2014 about Local Government. In connection with it, SubDistrict Head exercises governmental authority from 2 (two) sources, namely: the field of authority within the scope of the general tasks of government, and the authority of the field of government delegated by the Regent in the context of implementing regional autonomy. ${ }^{13}$

\section{Government Regulation Number 43}

of 2014 about Rules for

Implementing Village Laws

\footnotetext{
${ }^{13}$ Interview with Jaka Santoso, dated on $5^{\text {th }}$ of February 2020 in Central Bengkulu Regency Government Section.
}

Bengkoelen Justice, Vol. 10 No.2 November 2020

The implementation of village authority is based on the origin and local scale authority of the village funded by the APBDes, and can also be funded by the $A P B N$ and $A P B D$ from the Province and Regency/City. The budget for exercising village authority that obtained or assigned by the Central Government is funded by $A P B N$ through an allocation from the budget portion of the Ministry/Institution and is channeled through the SKPD-Regencies/Cities Regional Working Unit. Besides, the implementation of village authority obtained through the Local Government will be funded by the $A P B D$ from Province and Regency/City. Management of APBDes sourced from the Regency $A P B D$ requires supervision from the subdistrict head as part of the Local Government. Also, the Local Government, in this case, the Regent, must make an inventory of the authorities in the village and then regulate it in the Regent Regulations to be used as a guide for the village in compiling a list of village authorities. This is by Article 37 of Government Regulation Number 43 of 2014 concerning Regulations for Implementing Law Number 6 of 2014.

\section{Government Regulation Number 17} of 2018 about Sub-District

The delegation of part of the Regent/Mayor's authority to the Sub- 
Neny Zarniawati, Elektison Somi, Amancik

District Head was carried out to make effective the administration of local government in the sub-District and to optimize public services in the subDistrict as the local devices who dealing directly with the community. As regulated in Article 10 letter (g) and letter (h) Government Regulation Number 17 of 2018 about sub-Districts. ${ }^{14}$ Based on this Article, it can be concluded that the SubDistrict Head has a very important role in the context of supervising the village administration. As the spearhead of service to the community, the Sub-District Head has the duties and responsibilities that must be carried out in the context of carrying out the tasks of government, service, and development.

\section{Regulation of the Minister of Home}

Affairs Number 20 of 2018 about

\section{Village Financial Management}

Based on the provisions of Article

37 of the Minister of Home Affairs

Regulation Number 20 of 2018 concerning Village Financial Management which reads: ${ }^{15}$

"The Regent/Mayor can delegate the evaluation of Draft Regulation of the Village about Village Budget to the sub-District Head or other

${ }^{14}$ Article 10 letter (g) and letter (h) Government Regulation Number 17 of 2018 about Sub-Districts.

15 Article 37 Regulation of the Minister of Home Affairs Number 20 of 2018 about Village Financial Management.
Bengkoelen Justice, Vol. 10 No.2 November 2020 designations".

This delegation of authority is intended to create effectiveness and efficiency in the administration of government, while at the same time improving public services in the regions. Then in the delegation of authority, there are goals and benefits, one of which is to accelerate decision making related to the interests and needs of the local community. That means the interests and needs of the local community are immediately realized or implemented.

\section{The Regent's Regulation of Central}

\section{Bengkulu Number 34 of 2018}

Regarding the Authority Delegation

of the Regent to the Sub-District

Head in Evaluating Draft

Regulation of the Village Regarding

Village Budget and Draft Regulation

of The Village about Village Budget

Amendment.

In article 2 paragraph (1) of the Regent's Regulation of Central Bengkulu Number 34 of 2018 Regarding the Authority Delegation of the Regent to the SubDistrict Head in Evaluating Draft Regulation of the Village Regarding Village Budget and Draft Regulation of The Village about Village Budget Amendment, which reads:

"The Regent delegates authority to Sub-District Head in evaluating Draft Regulation of the Village 
Regarding Village Budget and Draft Regulation of The Village about Village Budget Amendment".

Based on the Regent's Regulation, SubDistrict Head in Central Bengkulu Regency is carrying out the function as the Evaluator of the Raperdes on APBDes and the Raperdes on P-APBDes. However, in fact, several sub-districts in Central Bengkulu Regency, the SubDistrict Head only issues a Sub-District Decree that the APBDesa has been verified so that there is always no record from the Sub-district to the Evaluation results and rarely published in written about the narrative conclusions that regulated in the evaluation steps in the attachment of Central Bengkulu Regent's Regulation No. 34 of 2018 regarding Authority Delegation of the Regent to the Sub-District Head in Evaluating Draft Regulation of the Village Regarding Village Budget and Draft Regulation of The Village about Village Budget Amendment. ${ }^{16}$ As a result, it causes Village Community Empowerment Office as the agency to supervise village finance must re-evaluate the Village Regulation on APBDes and caused the delay in the process of disbursing the Village Fund in Central Bengkulu Regency.

The factors that become obstacles

16 Interview with Tomi Marisi, 29th of January 2020 at the Village and Community Empowerment Office. in the implementation of the delegation of authority of the Sub-District Head in evaluating APBDesa in Central Bengkulu Regency are divided into:

Legal Substance Factors, including strict sanctions to the Sub-District Head not yet regulated if the Sub-district does not carry out the obligation to make an Evaluation Report as outlined in the form of a SubDistrict Head Decision and Minutes of Evaluation Results, not yet regulated in detail regarding the main tasks and functions of the Team Guidance and Control, there is no maximum supervision of the evaluation process carried out by the Sub-District Head, there is no article in the Regent's Regulation that clearly states the Sub-District Head's obligation to make Operational Standards Procedures for Raperdes Evaluation Process Regarding APBDes and $p$-APBDes, and there is no systematic factor in the APBDes evaluation process;

1. Legal Structure Factors, including the lack of detailed technical guidance in APBDes evaluation by the Sub-District Head so that the evaluation process in the Sub-District team 
often exceeds the maximum evaluation time limit. This is influenced by many processes and stages in the APBDes evaluation that are neglected at the sub-District level, the Resource factor where the lack of capacity of both the Village Apparatus and the sub-district evaluation team, and the delegation of part of the Regent's authority to the sub-District Head in Central Bengkulu Regency should be accompanied by the transfer of funding, therefore the Sub-District Head and other APBDes Evaluation Team do not experience difficulties in carrying out this authority;

2. Legal Culture Factors, including the lack of communication between parties involved in the evaluation process of the Draft Regulation of the Village on APBDes and P-APBDes and the lack of desire of individuals who are members of the Raperdes Evaluation Team on APBDes and APBDes Amendments to better understand the mechanisms and material of the evaluation itself.

\section{CLOSING}

\section{Conclusion}

The authority of the Sub-District Head in evaluating Draft Regulation of the Village Regarding APBDes and APBDes Amendments in Central Bengkulu Regency is carried out based on the mandate that stipulated in:

a. Law Number 6 of 2014 about Village;

b. Law Number 23 of 2014 about Local Government;

c. Government Regulation Number 43 of 2014 about Rules for Implementing Village Laws;

d. Government Regulation Number 17 of 2018 about Sub-Districts;

e. Regulation of the Minister of Home Affairs Number 20 of 2018 about Village Financial Management;

f. The Regent's Regulation of Central Bengkulu Number 34 of 2018 Regarding the Authority Delegation of the Regent to the Sub-District Head in Evaluating Draft Regulation of the Village Regarding Village Budget and Draft Regulation of the Village about Village Budget Amendment.

The factors that become obstacles to the implementation of the authority of Sub-District Head in evaluating APBDesa are distinguished into factors of legal substance, legal structure, and legal culture. 


\section{Suggestion}

Revising the Regent's regulation of Central Bengkulu Regulations Number 34 of 2018 by further emphasizing the function of the Sub-district head's evaluation and supervision of the Village, including to reinforce the evaluation and supervision guidelines by the Sub-District Head. And it is necessary to do more intense socialization about the authority delegated by the Regent to the subDistrict Head to increase the capacity and capability of human resources both of the Village Apparatus and the sub-district evaluation team that will carry out the delegation of authority.

\section{BIBLIOGRAPHY}

Amirudin, Zainal Asikin, 2004, Pengantar Metode Penelitian Hukum, Jakarta, Raja Grafindo persada.

M.Endriyo Susila et al, $2007 \mathrm{Buku}$ Pedoman Penulisan Hukum, Yogyakarta: Faculty of Law, University of Muhammadiyah Yogyakarta.

Mukti fajar and yulianto achmad, 2017, Dualisme Penelitian Hukum Normatif dan Empiris, the fourth printed, Yogyakarta, Student Library.

Safri Nugraha, et al, 2007, Hukum Administrasi Negara, Central For Law and Good Governance Studies, Faculty of Law, University of Indonesia.

Article 209 Paragraph (2) Law Number 23 of 2014 concerning Local Government.
Article 87, Government Regulation No. 43 of 2014 concerning Regulations for the Implementation of Law No. 6 of 2014 concerning Villages.

Article 9, Paragraph (1), Minister of Home Affairs

Article 101 Paragraph (4) Government Regulation Number 43 of 2014 Concerning the Implementation of Law Number 6 of 2014 concerning Villages.

Regulation of the Minister of Finance of the Republic of Indonesia No. 225/PMK.07/2017 Regarding the Second Amendment to the Minister of Finance Regulation No. 50/PMK.07/2017 Regarding Management of Transfers to Local and Village Funds.

Article 112 paragraph (2) of Law Number 6 of 2014 about Village.

Article 10 letter (g) and letter (h) Government Regulation Number 17 of 2018 about Sub-Districts.

Article 37 Regulation of the Minister of Home Affairs Number 20 of 2018 about Village Financial Management. 